джерела, які здатні суттєво допомогти у вивченні матеріалу. Таким чином саме використання комп'ютерних технологій під час навчання, студент виховується самодостатнім фахівцем, який буде спроможний реалізуватися в бурхливому та постійно змінюючому житті.

\title{
Література:
}

1. Мінцер О.П., Вороненько Ю.І. Дистанційна освіта і телемедицина: Аналіз напрямку. Медична газета. 2005. № 9. С. 4-5.

2. Філіппова Л.В. Використання інформаційних технологій під час навчання хімічних дисциплін Педагогічні науки, 2014, Херсон, вип. LXVI, (66). С. 472-476.

3. Філіппова Л.В. Роль хімічного експерименту в фармацевтичній освіті. „Проблемы современного педагогического образования», Сер.: Педагогика и психология. Сборник статей: - Ялта: РИО ГПА, 2016. 2016. - Вип. 50 (3). С. 197-203.

4. Безпалько В.П. Слагаемые педагогической технологии / Безпалько В.П. - М. : Педагогика, 1989. - 192 с.

DOI https://doi.org/10.30525/978-9934-588-80-8-2.50

\section{СУГЕСТИВНИЙ МЕТОД ВИКЛАДАННЯ УКРАЇНСЬКОЇ МОВИ ЯК ІНОЗЕМНОЇ}

\author{
Цуркан М. В. \\ кандидат філологічних наук, \\ доиент кафедри суспільних наук та українознавства \\ ВДНЗ Украӥни «Буковинський державний медичний університет» \\ м. Чернівиі, Украӥна
}

Актуальним напрямом сучасної лінгводидактики $\epsilon$ викладання української мови як іноземної, що зумовлено розширенням векторів діяльності закладів вищої освіти України, зокрема підготовкою іноземних фахівців різних галузей. Особливу роль в освітньому процесі інокомунікантів відіграє оволодіння ними українською мовою, адже від уміння спілкуватися українською залежить тривалість процесу адаптації іноземців та їх входження в україномовне суспільство. Тому основним завданням методистів і викладачів вищезазначеної дисципліни $є$ добір найбільш ефективних методів навчання мови як способів досягнення освітніх цілей. 
Метод навчання української мови як іноземної трактуємо як спосіб реалізації освітньої, розвивальної та виховної мети навчання, спрямований на організацію ефективного освітнього процесу, основним завданням якого $є$ досягнення бажаного результату.

У методиці викладання іноземних мов найбільш ефективними методами навчання вважають такі методи, як прямий метод, свідомозіставний метод, свідомо-практичний метод, граматико-перекладний метод, сугестивний метод, аудіолінгвальний метод, аудіовізуальний метод. Жоден із перелічених методів не $\epsilon$ універсальним, тому лише сукупність виокремлених методів сприяє досягненню мети навчального процесу. У процесі навчання української мови як іноземної в медичному ЗВО також упроваджуємо вищезазначені методи, однак варто відзначити те, що одні з них лише частково забезпечують вирішення поставлених завдань (сугестивний, граматико-перекладний), інші ж методи $є$ доречними впродовж вивчення і засвоєння всього навчального матеріалу.

Сугестивний метод (від лат. suggestio-навіювання) уперше запропонував застосовувати в освітньому процесі болгарський учений Г. Лозанов у другій половині XX ст. Педагогічні та теоретичні аспекти застосування цього методу в навчальному процесі також описані в дослідженнях С. Гончарова, Г. Китайгородської, С. Ніколаєвої, С. Пальчевського, О. Пєхоти та інших, які стверджували, що сугестивний метод навчання уможливлює оволодіння іноземною мовою за короткий термін. В основі цього методу, як зазначив Г. Лозанов, гіпотеза про неусвідомлювану психічну активність, яка в безпосередньому зв'язку 3 усвідомлюваною активністю особистості є носієм не тільки інтенсивних тенденцій, а й вторинно-автоматизованої діяльності, що зумовлює будьяке навчання та будь-який розвиток людини [1, с. 109]. За твердженням С. Пальчевського, «навчальні принципи сугестопедії передбачають відчуття радості від навчання, яке відбувається в стані психологічного комфорту, використання сугестопедом (викладачем) поряд із усвідомленими реакціями i функціями школяра (студента) його парасвідомої активності, організацію навчально-виховного процесу на рівні не використовуваних за умов традиційного навчання резервів учня (студента)» [2, с. 29].

Упровадження сугестивного методу в процес вивчення української мови іноземними студентами-медиками буде доцільним під час подання лексичного матеріалу шляхом участі студентів у рольових іграх, слухання ними пісень, полілогів, перегляду театралізованих сцен тощо. Усі ці види діяльності здійснюються у повільному темпі, часто супроводжуються музикою, перекладом, невербальними засобами, що 
допомагає усунути психологічні бар'єри, страх помилитися, скутість, які часто виникають у ситуаціях навчання, встановити довірливі стосунки між викладачем і студентами, спонукати студентів до сприйняття лексем на розмовному рівні. Необхідно зазначити й те, що використання цього методу в навчальному процесі дозволяє іноземним студентам засвоїти великий обсяг інформації, перебуваючи в стані релаксації (розслаблення), що в свою чергу сприяє інтелектуальному зосередженню іноземця та підвищенню потенціалу його розумової працездатності, а також знімає стрес, напруженість, знижує втому. Описаний метод використовуємо під час проведення практичних занять, на яких студенти працюють із автентичними текстами, зокрема текстами українських пісень, поезій тощо; а також у процесі позааудиторного навчання, а саме: відвідування музеїв, театрів, екскурсій, перегляду фільмів тощо.

Як бачимо, сугестивний метод навчання спрямований на розкриття резервних можливостей особистості, в основі яких неусвідомлювана психічна активність, що уможливлює засвоєння іноземної мови за короткотривалий період. Сугестопедичне навчання української мови як іноземної $є$ не лише способом засвоєння мови інокомунікантами, а також надзвичайно важливим i дієвим інструментом адаптації іноземного студента в «чужому» суспільстві, оскільки саме навіювання, а далі й наслідування сприяють автоматизації як комунікативних, так $\mathrm{i}$ поведінкових актів людини у відповідних сферах діяльності. Означений метод викладання іноземної мови, зокрема української, активізує мовленнєву діяльність іноземця та пришвидшує процес його соціалізації в іншомовному середовищі.

Отже, сугестивний метод навчання української мови як іноземної у поєднанні з іншими традиційними та інтерактивними методами навчання забезпечать оволодіння іноземними громадянами українською мовою та сприятимуть здобуттю інокомунікантами якісної професійної освіти.

\section{Література:}

1. Лозанов Г. Основы суггестологии. София, 1973. 225 с.

2. Пальчевський С. Сугестопедагогіка: новітні освітні технології: навч. посібник. К. : Кондор. 2005. 351 с. 